\title{
Capitalizing Human Capital: The Role of Instrumental Leadership
}

\author{
Yessie Fransiska Lydiana, MSMa*, Yuni Ros Bangun, MBA ${ }^{a}$ \\ ${ }^{a}$ School of Business and Management ITB, Jl. Ganesha No. 10, Indonesia \\ *Corresponding author: yessie.fransiska@sbm-itb.ac.id
}

Article history

Received :4 April 2013

Received in revised form :

25 July 2013

Accepted :15 October 2013

\begin{abstract}
It is important for company to maintain their sustainability. Today human issue becomes very important, company realizes that people is their asset and capital. The most important from this issue is how to capitalize human capital. This paper also tries to find the influence of instrumental leadership toward capitalizing human capital. Analytical literature review as a methodology is trying to find the correlation between capitalizing human capital and instrumental leadership. It is found that theoretically, instrumental leadership plays an important role in capitalizing human capital. This paper contributes to the business world; explicitly in company's efforts to capitalize their employee. Based on this literature, company must evaluate their leadership style; because this research finds the significant effect of instrumental leadership.
\end{abstract}

Keywords: Human capital; leadership; instrumental leadership; competitive advantage

(C) 2013 Penerbit UTM Press. All rights reserved.

\subsection{INTRODUCTION}

The term human capital is originated from Theodore Schultz, an economist interested in the plight of the world's underdeveloped countries. Schultz has an argument that the traditional economic concept is no longer matched with today situation. Schultz claimed that improving the welfare of poor people did not depend on land, equipment, or energy, but rather on knowledge, called this qualitative aspect of economics human capital. Schultz, who won the Nobel Prize in 1979, offered the description that reflects on all human abilities either innate or acquired; every person is born with a particular set of genes, which determines his innate ability. Schultz added that attributes of attained population quality, which are valuable and can be enlarged by appropriate investment, will be treated as human capital. The almost infinite variability and unpredictability of human beings make them enormously more complex to evaluate than one of the electromechanical components that comes with predetermined operating qualifications.

Based on Schultz understanding, people are the only elements with the inherent power to generate value. The most important issue is how to fulfill people in their work, so they can deliver their value in their job. No amount of compensation can restore the soul of a person who has spent his or her life in mindless toil.

In nowadays reality company owners or the leaders of company believe that providing tangible incentives, the human equivalent of food pellets, is the answer. The fact is that it doesn't matter how tasty the incentives might be; a pigeon who doesn't know which lever to peck is not going to get a pellet. In the other words if we don't have people with inherent talent, training, or work experience, along with the right tools and information to do the job; we are not going to get the results as we need.
To maintain a competitive position in the marketplace of the twenty-first century, management will have to find methods for increasing the power of human capital. The availability of valid and reliable performance data is at the heart of the issue. The most cost-effective, long-term solution to the talent shortfall lies in helping each person to become more productive. This charges management with the task of figuring out how to capitalize in human capital.

Ulrich (1999) stated that capitalizing human capital can be accomplished by making the employees feel valued, unique and appreciated by their company. The employee behavior within firms has important implication for organizational performance, the human capital practices can affect employee performance through their influence over employees' skills that allow them to improve how their jobs are performed. Rhoades and $\mathrm{R}$. Eisenberger (2002) reviewed more than 70 scientific studies resulting that employees who feel valued are more dedicated to the organization, increase job satisfaction and mood, decrease lateness, uncertified sick leave and turnover in work.

As the previous study has proven, it is important to increase the power of human capital since it has significant impact to employee performance; this literature tries to figure out how to capitalize human capital.

The leadership style is assumed as the predetermined factor in capitalizing human capital. How leaders direct the company will determine the future of the company, also how they treat the subordinates or employees can make a significant impact to employee's performance directly to company performance. The new approach of leadership style is instrumental leadership, which one of the indicators is follower work facilitation. Leaders' role today is not just only giving order or checking their subordinate work, but the employees also strive their leader to be more proactive and more involving, coach them, care about their job 
and difficulties and facilitate them to achieve their goals. This type of leader expected can support the process of capitalizing human capital.

With the problem faced by company today, the influence of leader's role and corporate value is likely to generate employee's value. This literature review will present theoretical and research literature related on how to capitalize human capital, and the role of instrumental leadership, furthermore the influence between them.

\subsection{LITERATURE STUDY}

\subsection{The Concept of Human Capital}

Dynamic change, as well as innovation, demands robust human capital that is fully engaged and agile, aggressively developed and skillfully deployed. Yet, despite an overwhelming need to draw upon it, human capital still remains a lightly tapped resource. Are organizations supposedly enamored with the value of human capital or just unaware of what it takes to leverage such a powerful asset?

John Ingham (2007) defines human capital as the relevant knowledge, skills, experience and learning capacity of the people available to the organization. This definition leads to the thoughtful in management of this human capital, HCM, as a strategic approach to people management that focuses on the issues that are critical to organization's successes. It also highlighted that HCM is a performance, not a social issue that treats human capital as a positive - and active - asset to be developed, not a passive cost.

As Baron and Armstrong stated in their book, human capital is an important element of the intangible assets of an organization. The other intangible assets include copyright, customer relation, brand and company image. In line with John Ingham understanding about human capital, Becker et al,. (2007) stated human capital is referred to as employee's knowledge, know-how, ideas, skills, capabilities, commitment, and health which add economic value to firms. In addition to the combination of knowledge, education, skills, attitudes, Bart (2001) added experience in human capital definition. Garavan, 2001 cited that adaptability, flexibility, and employability are the aspects which act as catalysts for the evolution of human resources into human capital.

Human capital can encompass knowledge, skills and technical ability, personal traits such as intelligence, energy, attitude, reliability, commitment, the ability to learn, including aptitude, imagination and creativity, and the desire to share information, participate in a team and focus on the goals of the organization.

Bontis (1999) stated that human capital particularly represents the individual stock of knowledge implanted in the firm's collective capability to extract the best solution from its individual employees. A line with Bontis, Edvinsson and Malone define human capital as the sum of the workers' skills, experiences, capabilities, and implicit knowledge. Added by Davenport and Prusak in 1998, human capital includes the intangible resources of abilities, efforts, and time that workers bring to invest in their work.

Concluding all definitions above; human capital is not just important for company but also unique source of competitive advantage that is difficult for its competitors to replicate, because in human capital embedded all the people's potentials which can continuously enlarge and become usefully company's asset.

\subsection{Capitalizing Human Capital}

The term capitalizing can be defined as development or exploitation, the act of making someone or something more profitable or productive or useful. When an item is capitalized, the value of the item is placed in an asset, which increases the value of the company. The term of human capital recognizes that people are investors of their personal human capital and that this provides the main source of value for an organization. Of course, financial reporting standards will not allow us to account for human capital in the same way as financial capital, but with a nominal shift from the right-hand to the left-hand side of the balance sheet, the term human capita at least implies the right level of importance. It describes an investment, not a cost.

Money spent on improving employees is one of the best investments that business executives could make (Owen, 1825). The success of these organizations largely depends on the quality of their human resources. The characteristic that differentiates successful organizations from their less successful counterparts in almost every industry is the quality of the people they are able to get and keep. These successful organizations do invest heavily in employee training to make sure that their employees' skill levels are kept current (Robbins, 2001).

Human capital is primed to become a more leading variable and a key driver of productivity and profit. It is certainly the most abundant, flexible and readily leveraged resource organizations have.

Human resources department transforms to become human capital development, by this new term which says that employee as an investment, expected that can create competitive advantage for company. Shifting to the human capital term company is no longer trivial to the importance of human in company. Employee has become the important part and become company competitive advantage. Human capital management is expected to result the employee with high capability and the positive impact to company performance.

Company shifted to focus on human capital creation to achieve and sustain the advantage, since high value and unique human capital are firms' core competencies. Ulrich et al., in 1999 mentioned that from economic perspective, human capital is defined in a firm as the proportion of market value to the replacement value of fixed assets.

Snell and Bohlander, 2007 said that human capital is an employee's knowledge, skills, capabilities, commitment, knowhow, as well as ideas and health which sourced from employee perspective. Now, the companies realize the huge contribution of human capital on achieving competitive advantage; they begin to shift their focus from employee development to human capital development.

Human capital approach is how to make employee feel high valued and unique (Ulrich et al., 1999). Making the employee feel high valued and unique, the company can capitalize their human capital so it increases the value of the company. This approach expected that company can maintain the employee and make them perform well, due to making employee feel high valued and unique, the company will have people who think in a new way, with a workforce that is constantly learning, adjusting and adapting to new technology (Chris Collins).

Morone and Taylor in 2004 state that the process of human capital designs to the employee is initiated when employee takes effort to involve in self and interactive learning. Ulrich has opinion that organization develops human capital by simultaneously increasing both employee's capabilities and commitment.

The company can capitalize their human capital by referring to employee perceived human capital creation, the degree to 
which employees feel human capital creations when efforts are taken from mutual benefits of both employees and organization. According to the thought company can capitalize their human capital when an employee delivers better performance for organizational activities, wage improvement is more likely to occur (Birasnav et al., 2011). Another indicator of how company capitalizes their human capital is referred to Ulrich et al., 1999, when organization considers employee as a future leader, because they have potential to vertically move into an influential position. The other thing is when employee gets opportunity to participate in a high profile project or cross functional teams. Harley in 1990, employee also perceived the potential of their human capital is when company increases their authority and status through skill development.

Ulrich (1999) stated that employee feels that they are capital when the company valued them. Valued by the company is another way to capitalize human capital. According Rhoades and R. Eisenberger, 2002, when the employee is given approval and respect, good working condition, and access to information and other resources to carry out their job, and offered better pay and promotion, the employees feel valued by the company. Having employees who feel valued, they are likely to be committed to the organization.

Perceived organizational support refers to an employee's beliefs about the organization they work for: how much it values their contribution, cares about their wellbeing and is ready to offer help when needed. At the time employees consider the way they have been treated, they build up beliefs about whether or not the organization values them. Employee perceived organizational support is the point to which they feel valued by the organization they work for. When the organization offers care, approval and support, this helps to fill employee's emotional and social needs.

An encouraging organization strengthens the employee's expectation that hard work and high performance will be rewarded and it will enhance job satisfaction and mood, improve commitment and performance, decrease turnover. There are three main factors that make employees feel value referred to perceived organizational support; fairness in the workplace, support from supervisors, and rewards and good job condition.

\subsection{Leadership Definition}

The term of leadership has been known since many years ago. Plato said that only a few of superior wisdom can be a leader. Aristotle had an opinion that from the moment of the people birth, some are marked for overthrow and others for command.

Different from Plato and Aristotle, Machiavelli felt that those princes who had the wiliness and the ability to organize power and knowledge in the defense of the state should be followed. Machiavelli's opinion is that people are weak, imperfect, easy to fool, and dishonest; therefore, manipulation is acceptable to achieve one's goals when the end validates the means.

Over the past 100 years, leadership has become a topic of interest in various disciplines. Tannenbaum et al. (1961) provide a definition for leadership as interpersonal influence, which is implemented in a situation, and directed through the communication process, toward the achievement of a particular purpose or goal.

Studies on leadership in organization have moved several directions, but two approaches have dominated the literature. The first approach has focused on the leader's characteristic and behavior, and the second on the circumstances necessitating the demonstration of leadership and the possible result of different leadership style. Among various literatures of leadership, the appropriate definition shall depend on the theoretical, methodological, and substantive aspects of leadership being considered. This means that researcher can choose the leadership theories based on available scientific literature in which the concept of leadership has been studied in a particular field or discipline.

The early theories tend to focus leadership as the behaviors and characteristics, successful leaders, and then the theory began to consider the role of follower and contextual nature of leadership. The contemporary view seems to embrace the situational approach in particular. From this view, it is the leader's responsibility to analyze the factors present in each set of circumstances. From the analysis, the appropriate leadership actions can be determined. Fiedler says to look at leader-member relations, task structure, and position power. By using these factors, a decision can be made about the use of task-oriented or relationship-oriented behavior.

Path-goal leadership uses the clarity of task definition, the ego-involvement of the subordinates, the repetitive nature of tasks, and the level of a subordinate's motivation, along with other clues, to determine whether directive, supportive, participative, or achievement-oriented leadership is needed. It is possible to develop an analytical grid to evaluate leadership needs. Fiedler would suggest changing leaders to fit situational requirements. Other models would call for the leader to adjust his or her technique to fit the circumstances. Most models suggest the value of consistent treatment of employees. The ideal that leadership is providing an employee with the support, information, and guidance to do the job effectively seems pertinent. Some workers, of course, need much support, while others need very little.

Trait approach is the approach to the nature of the earliest theories of leadership, evolved from the Great Man theory which states that the great man was born not made. Trait theory emphasizes the leader's personal qualities and attributes that distinguish the focus of leaders from non leaders.

Daft (2005) stated that behaviors can be learned more readily than traits, enabling leadership to be accessible to all. Daft (2005) divided this approach into two: Autocratic and Democratic. Michigan University took different ways. They divide the leader who effective and ineffective. Fiedler's contingency theory postulates that there is no single best way for managers or leaders to lead.

The previous research failed to find the universal model for leader traits and behaviors. The behavior approach might be effective in several conditions, but becomes ineffective under different situation. This fact led the researcher to the theories which called contingency approaches. Contingency means that one thing depends on other things, and it means that the leader can be effective if there is appropriate fit between the leader's behavior and the situation. One of researches which developed this model is Fiedler's.

Another contingency theory is the path-goal theory. Based on this theory, the leaders have responsibility to increase motivation of their subordinates to attain personal and organizational goals. The others model used contingency approach is The Vroom-Jago Contingency. This model focused specially on varying degrees of participative leadership, and how each level of participation influences quality and accountability of decision.

Based on Vance and Larson (2000), there are two major paradigms that have provided the basis for the study of leadership among disciplines over the past two decades, transformational and transactional leadership. Bass (2007) defined transformational leaders as role models for employees, motivate them, and stimulate their intelligence. De Jong and Den Hartog (2007) mention that transformational leadership in organizations attracted much attention because it contributed to the company's innovation, organizational learning, and employee's creative 
skills, although each kind of leadership style has its own advantage and disadvantage.

Vance and Larson (2003) stated that transformational and transactional leadership are two major paradigms of leadership that became foundation for the study about leadership among disciplines for two decades.

\subsection{Instrumental Leadership}

Antonakis and House in 2002, define instrumental leadership as a class of leader's behavior which concerns the performance of leader expert knowledge toward the fulfillment of organizationallevel and follower task performance. Instrumental leadership is different from transformational and transactional leadership and encompasses two subclasses of leader behaviors. The first subclass is strategic leadership, which consists of two factors.

Strategic leadership is leader action centered on environmental scanning and strategy formulation. Katz and Kahn stated that strategic leadership means having knowledge of the lack and opportunities of the external environment and the organizational system is essentials element of leadership.

Antonakis and House conceptualized the terms of strategic leadership in two distinct factors; environmental monitoring, as expressed by Conger and Kanungo in 1998 along with House and Shamir in 1993 and strategy formulation and implementation, as proposed by Sashkin in 1998 in addition to Westley and Minzberg in 1998.

Supposedly, the strategic leadership directly influences and improves organizational effectiveness. Strategic leadership also helped charismatic effects, because the identification of deficiency in status quo and the expression vision that can project a better future in the function of the ability of a leader to use the skills of strategic leadership.

Another subclass is follower work facilitation which defines as leader actions focused on facilitating follower performance. Bowers and Seashore in 1966 saw follower work facilitation as the type of leadership that facilitates follower performance directly.

According to House (1997) work facilitation includes element of the path goal theory, not dealing with in conditional reward leadership which was suggested by Bass in 1985, and an active-constructive outcome monitoring form of leadership as mentioned by Antonakis and House in 2002. For this work facilitation, leader behaviors include path-goal facilitation and monitoring of results. Follower work facilitation leadership has a great responsibility for monitoring performance results and provides feedback instrument for the achievement of objectives, compensation for the ability of followers and environmental conditions to ensure that the followers reach their goals, and increase the likelihood that the valence followers maximized. This behavior will increase the followers' self-efficacy and motivation.

Donald Hambrick (1989) in Strategic Management Journal (SMJ) defines the strategic leadership by focusing on the people who have overall responsibility for an organization, the characteristic of those people, what they do, and how they do. Hambrick in Sage 2011 argues that the strategic leadership task can be distinguished from leadership at other levels of the organization in four ways, strategic leadership demands a focus on both the internal and external environments of the organization and a concern with positioning it within its context, strategic leadership tends to involve the navigation of greater degrees of complexity and ambiguity than leadership at other levels, strategic leadership is multifunctional and integrative in contrast to the often more specialized task of operating management, unlike leadership at the front lines, strategic leadership involves leading through other leaders.
Strategic leadership does not only understand relationship between leaders and followers, but also how to coordinate the decision and activities that will orient the future of the organization. The previous literatures focused on learning from leadership as an individual; character, behavior, approach, or the habit which can be seen. That approach hasn't connected the relationship between micro and macro level analysis.

Antonakis and House in Bangun 2010, continue their study and introduce the model of instrumental leadership. They stated that in many times transformational leadership makes the leaders not brave enough to take unpopular decision in crisis that can make the group or employee suffered in crisis time. In one of the researches Antonakis found that the leader must have ability to think to analyze external business environment. In addition to the transformational, transactional and laisez faire leadership, the strategic behavior and follower facilitation must be added. Bangun 2011 stated that this model will be beyond the transactional and the transformational model by involving the strategic element and follower facilitation, which is very important to maintain the organization synergy and subordinate performance.

\subsection{Capitalizing Human Capital and Instrumental Leadership}

The term of capitalizing brings us to the efforts that make someone or something become more productive and profitable. In terms of business, company needs to capitalize their asset so they can face and win the competition and maintain their sustainability. Based on the understanding of the phrase of human capital, people become company asset which turn into dominant factor and key driver of productivity and profits.

The company is trying to find the best way to capitalize their human capital. According to the literature there are theories that direct us to the way of capitalizing human capital. The employee will be more productive if they perceived as human capital (Birasnav, 2011). Employee perceived as human capital by giving them training and increased compensation as they perform better. It can't be denied that compensation still becomes the attractive thing that makes employee interested in one job, but nowadays employees need compensation as measurement for all they have done for company. The compensation cannot be flat anymore but they must be increased as the employee's performance better. The need of training is no longer as a company cost but as company investment through the employee. So now the employees expect higher position along they received more training.

Ulrich, 1999 has different statement, that employees perceived human capital when company gives them opportunity as future leader and participating in company's hi project. There is changing of employees today, they feel not enough for the compensation they have from company, and company must offer something more. The opportunity to learn and grow in company becomes compulsory for employees now days, giving the chance to be a future leader will increase the motivation of employees to perform well and stay at the company. The same thing as opportunity to participate in hi project, can arise the employee's confidence and motivation and it's the way to capitalize the people. Harley (1990) gave opinion, giving employee increased status and authority is the way to make employee perceived human capital.

As stated above the way to capitalize human capital is by giving the employees the tangible compensation such as wage, bonus, health insurance etc, but it can't stop there, the employees also need the recognition for their contribution. Rhoades and Eisenberger (2002) give another paradigm on how to make employee perceived human capital, it's by making them feel valued by the company. Rhoades and Eisenberger also mentioned 
what makes employee feel valued; the first one is fairness in the workplace. If we talk about fairness we'll converse in terms of performance appraisals, procedural variables may be more important than outcome variables as determinants of the perceived level fairness by employees (Greenberg, 2002). An organization that provides knowledge to employees about procedures demonstrates regard for employees concerns. Decision-making processes that are unclear to employees break procedural fairness and trust - damaging the employer-employee relationship.

The other thing is support from the supervisor, supervisor plays important role in determining work environment, providing information and feedback of employees. The supervisor expected as a guide and also a partner for employee to achieve their goals. The supervisor is the one who knows the ability and performance of employees, that's why supervisor can give influence directly to employee.

The last thing that Rhoades and Eisenberger found about making the employee feel valued are rewards and good job condition. Eisenberger, Huntington, Hutchison, and Sowa (1986) suggested that, to meet needs for approval, affiliation, and esteem and to determine the organization's readiness to compensate increased effort with greater rewards, employees form a general perception concerning the extent to which the organization values their contributions and cares about their well-being. The perception of being valued and cared about by the organization would encourage the incorporation of organizational membership and role status into the employee's self-identity and thereby increase prosocial acts carried out on behalf of the organization (Eisenberger, 1990 ).

It is believed that the ways described above could be the tools to capitalize human capital. The using of employee perceived human capital as an indicator of capitalizing human capital referred to the understanding that to get employees more profitable and productive is by realizing the existence of employee in the company and admit their contribution to company. It comes up with training, compensation, being future leader, opportunity to participate in hi project, and increased status and authority.

The second indicator is perceived organizational support that makes employee feel valued. For that reason it is not enough for company only to recognize employee performance but also company has to concern about employee well being. Company needs to be more concerned about the employees' need as a human being. This approach is to ensure the employees to work safely and comfortably. This approach contributes three indicators for capitalizing human capital, fairness in workplace, support from supervisor, rewards and good job condition.

In the process of capitalizing human capital, support from every element in company is needed. The role of leaders is considered important since leaders have the ability to influence, give the direction, and provide guidance and form the corporate culture. In terms of capitalizing human capital, there is a question, what kind of leader which can support and allow the process of capitalizing human capital is. The latent paradigm that employee as a cost still exists until today; the leaders that have the courage to change that paradigm are required. In addition to the leaders which have courage, the company also calls for the leaders who can read the business map and realize the need of change for company to sustain and win the business competition.

There are many studies related to leadership style, trying to find which leader is the most effective. It is believed that leadership style influenced the way employees behave and perform in company. Bass et al., in 2006 research resulted that those leaders who had characteristic of idealized influence, are more influential and willing to trust their employee. From many theories of leadership, instrumental leadership has own uniqueness.

The attention of most researchers regarding to leadership term is very huge. If we search in the searching engine we will find 5,590,000 items about leadership. With this phenomenon James $\mathrm{MaC}$ Gregor Burns stated that leadership becomes phenomenon that is most widely noticed but less understood. The developing of leadership term happened because of the shifting of the idea of leadership itself. As the assumption that leadership is solely born, shifted by the idea that leadership can be learned and done, if the situation requires. Similarly, developing leadership idea from extends of undeveloped foster skills, and then a leader saw the need to respect and understand and try to motivate their followers through rational and emotional approaches.

In the twentieth century, the evolution of the modern idea of leadership models reflects an understanding of the psychological motives of humanity either into or out of, in this case on social concern. Modern idea of leadership is to infuse a deep commitment to social goals in the individual, transform selfinterest into the wider or larger interest of social concerns.

Within each of ideas and practices in leadership changes, it seems that there is a consistency trend of increasing similarity between leaders and followers. From the traditional idea that the leader is the absolute ruler, to the idea that the leader's work is influencing their followers to do what leader seen as needs to do, and then shifted to the view in which leaders and followers must share deep commitment to the greater interests or objectives; the gap between the power and the role of leaders and followers is getting smaller.

There are several trends these days where the idea and practice of leadership heads to subsequent changes in leadership approach. Although the new form is still unclear, the change in leadership at this time shows the decrease in the distance between leader and follower. Currently there seems to be a tendency, leadership is understood as a process that plays reciprocal action.

The point is that people work together, regardless of the role of authority and power they are seen as partners, partners who need each other to determine together what makes sense, how to adjust the change, the direction-guiding vision, which is used to be provided by an individual leader.

This evolution does not mean that the old notion is abandoned altogether. For example, the concept of dominance in terms of the classical model of leadership is still alive today as well in terms or specific interests, the dominant leadership role. New notions of leadership emerge due to some limitations or previous models of leadership has been obsolete.

Antonakis (2004) stated that the term of transformational leadership has failed to address strategic and task oriented developmental function of leadership. Antonakis comes up with the idea of instrumental leadership which emphasizes in ensuring sustainable organization and follower performance. Leader has not been only confident and optimist, as transformational leadership stated, but also has to know the direction of the company and maximizing follower performance. Instrumental leadership divides into two classes, which each class consists of two indicators. The first is strategic leadership factor; instrumental leader must have the knowledge about the external environment and use it to analyze it so the company can be surviving in the competition. Strategic leadership consists of environmental monitoring and strategy firm and implementation. Environmental monitoring is referred to sensitivity of leader in reading external situation of company. Strategy firm and implementation is referred to the requirement of leader who is able to identify the lack of the company and articulate the vision which can make the future of company better. This type of leader theoretically can support the process of capitalizing human capital. The 
instrumental leader is expected to be able to bring the change to the company in order how the company treats the employee. The leader must see clearly that in today competitiveness employee has become the powerful weapon to be a competitive advantage. Companies no longer concerned only in capital and financial assets, and did not realize the potential of human capital. This fact demands that the role of leader who can bring changes in the company. The leaders not only had a vision for the company but also been capable to deliver the vision to the entire company so they together reach the vision. The efforts in achieving the vision should be able to be described by a leader appropriately to become strategies that can be implemented in the company.

The other factor of instrumental leadership is follower work facilitation. This factor consists of two indicators, the path goal facilitation and outcome monitoring. The path goal facilitation has an understanding that the leaders must encourage and support their follower in achieving goals. The leader must guide their followers to choose the best path to reach their goals. The other burdens of leader are to monitor and provide feedback to their followers so they can achieve the goals.

The requirement of instrumental leadership is also compensating their followers' ability, in addition to recognizing their performance, giving compensation, and the leader should be able to maximize the ability of their followers. Instrumental leadership has to be able to see the whole working environment, what makes employee perform well and not, leaders should ensure that the working environment supports employees to achieve their goals.

\subsection{CONCLUSION}

The process of capitalizing human capital in company requires the leader who understands the need of change, the leader who understands that employee nowadays becomes capital and company's weapon to win the competition. The requirements from a leaders has changed, not only to motivate, force employees, tells what is permitted and what is not, shows the power, but leader today also becomes strategic partner for employee. The leader must know what makes employee perform well, accommodate their need and omit the obstacle so they can achieve the goals. Having this type of leader, makes employees feel as an important and valuable asset in company, it makes them perform well and pull out their best effort for the company. The process of capitalizing human capital needs this kind of leaders; instrumental leaders are more concerned with the bottom line. The company who can see that changes are need to maintain their sustainability, must also make the whole company see that need. Today's leader must distribute a picture of the future reality with the organization's staff, constituents and the community. The instrumental leader understands the need for teams that will form the backbone of the integrated system.

\section{References}

[1] Birasnav, M., S. Rangnekar, A. Dalpati. 2010. Transformational Leadership and Human Capital Benefits: The Role of Knowledge Management. Leadership \& Organization Development Journal. 32(2): 106-126.

[2] Rhoades, L., R. Eisenberger. 2002. Perceived Organizational Support: A Review of the Literature. Journal of Applied Psychology. 87(4): 698714.

[3] Bassey, E. 2012. Capitalized Human Resources Cost and Its Influence on Corporate Productivity: A Study of Selected Companies in Nigeria International Journal of Financial Research. 3(2).

[4] Baron, A., M. Armstrong. 2008. Human Capital Management: Achieving Added Value Through People. London: Kogan Page
[5] Eisenberger, R., P. Fasolo, V. Davis. 1990. Perceived Organizational Support and Employee Diligence, Commitment, and Innovation. Journal of Applied Psychology. 75(1): 51-59.

[6] Day, D., J. Antonakis. 2011. The Nature of Leadership. Sage Publication.

[7] John Ingham. 2007. Strategic Human Capital Management Creating Value through People. Elsevier.

[8] Harris, J., S. Hartman. 2002. Organizational Behaviour. NY: The Haworth Press.

[9] Jac Fitz-enz. 2000. The ROI of Human Capital: Measuring the Economic Value of Employee Performance. Amacom.

[10] G. Becker. 1993. Human Capital: Theoritical and Empirical Analysis. The University of Chicago Press.

[11] Marimuthu, M., L. Arokiasamy, M. Ismail. 2009. Human Capital Development and Its Impact on Firm Performance: Evidence From Developmental Economics. The Journal of International Social Research. 2/8.

[12] António Martins. 2010. The Model of Intellectual Capital Approach on the Human Capital Vision. Journal of Management Research. 2(1): E10.

[13] Bontis, N., W. Keow, S. Richardson. 2000. Intellectual capital and business performance in Malaysian industries. Journal of Intellectual Capital. 1(1): 85-100.

[14] Seleim, A., A. Ashour, N. Bontis. 2007. Human Capital and Organizational Performance: A Study of Egyptian Software Companies. Management Decision. 45(4): 789-801.

[15] Stiles, P., S. Kulvisaechana. 2000. Human Capital and Performance: A Literature Review. The Judge Institute of Management

[16] D. P. Lepak, S. A. Snell. 1999. The Human Resource Architecture: Toward a Theory of Human Capital Allocation and Development. The Academy of Management Review. 24: 31-48.

[17] N. Bontis, and J. Fitz-enz. 2002. Intellectual capital ROI: A Causal Map of Human Capital Antecedents And Consequence. Journal of Intellectual Capital. 3: 223-247.

[18] B. Harley. 1999. The Myth of Empowerment: Work Organisation, Hierarchy and Employee Autonomy in Contemporary Australian Workplaces. Work, Employment and Society. 13: 41-66.

[19] Scott, S. and Bruce, R. 1994. Determinant of Innovative Behaviour: A Path Model of Individual Innovation in the Workplace. Academy of Management Journal. 37(3): 580-607.

[20] Harley, B. 1999. The Empowerment: Work Organization, Hierarchy and Employee Autonomy in Contemporary Australian Workplace. Work Employment \& Society. 13(1): 41-66.

[21] Phillips, J. J. 2005. Investing in Your Company's Human Capital: Strategies to Avoid Spending myth of Too Little-or Too Much AMACOM, New York, NY.

[22] Rowe, W. G. 2007. Cases in Leadership. Sage Publications, New Delhi.

[23] Wayne, S. J., Liden, R. C., Kraimer, M. L. and Graf, I. K. 1999. The Role of Human Capital, Motivation and Supervisor Sponsorship in Predicting Career Success. Journal of Organizational Behavior. 20(5): 577-95.

[24] Alban-Metcalfe, J. and Alimo-Metcalfe, B. 2009. Engaging leadership Part One: Competencies Are Like Brighton Pier. International Journal of Leadership in Public Services. 5(1): 10-18.

[25] Derek Stockley.2009. Human Capital Concept-Definition and Explanation. Google Website on the Human Capital Management Definition.

[26] D. Ulrich, J. Zenger, and N. Smallwood. 1999. Results Based Leadership. Boston: Harvard Business School Press.

[27] Yulk, Gary. 2002. Leadership in Organization. Prentice Hall. Upper Saddle River, NewJersey.

[28] Levey, S., Hill, J., \& Greene, B. 2002. Leadership in Health Care and the Leadership Literature. Journal of Ambulatory Care Management. 25(2): 68-74.

[29] Rafferty, A. E. and Griffin, M. A. 2004. Dimensions of Transformational Leadership: Conceptual and Empirical Extensions. The Leadership Quarterly. 15(3): 329-54.

[30] Bass, B. M. and Riggio, R. E. 2006. Transformational Leadership. Lawrence Erlbaum Associates. Mahwah, NJ.

[31] Podsakoff, P. M., MacKenzie, S. B. and Bommer, W. H. 1996 Transformational Leader Behaviors And Substitutes For Leadership As Determinants Of Employee Satisfaction, Commitment, Trust, And Organizational Citizenship Behaviors. Journal of Management. 22(2): $259-98$.

[32] Rafferty, A. E. and Griffin, M. A. 2004. Dimensions of Transformational Leadership: Conceptual and Empirical Extensions. The Leadership Quarterly. 15(3): 329-54.

[33] Nemanich, L. A. and Keller, R. T. 2007. Transformational Leadership in an Acquisition: A Field Study of Employees. The Leadership Quarterly. 18(1): 49-68 
[34] Wayne, S. J., Liden, R. C., Kraimer, M. L. and Graf, I. K. 1999. The Role of Human Capital, Motivation and Supervisor Sponsorship in Predicting Career Success. Journal of Organizational Behavior. 20(5): 577-95.

[35] Alban-Metcalfe, J. and Alimo-Metcalfe, B. 2009. Engaging Leadership Part One: Competencies are like Brighton Pier. International Journal of Leadership in Public Services. 5(1): 10-18.
[36] Antonakis, J., House, R. 2004. On Instrumental Leadership: Beyond Transactions and Transformations. UNL Gallup Leadership Institute Summit, Omaha. 